\title{
Editorial
}

\section{The CIA's vaccination ruse}

Journal of Public Health Policy (20I2) 33, 387-389. doi:I0.I057/jphp.20I2.37; published online 30 August 2012

In what others have already described as 'an incredibly stupid decision', the United States Central Intelligence Agency (CIA) chose in 20I0 to use a sham vaccination program to cover spying in Pakistan. ${ }^{1}$ Decisions that subvert public health activities can cause immense damage. Trust and credibility are crushed and health damage follows. So why have public health leaders in the United States remained largely silent? How can we be certain that we learn from this experience, and that it will never happen again?

The facts of the story are quite clear by now. Back in 2010, in the midst of a struggling national vaccination campaign to eliminate polio in Pakistan, the CIA enlisted a Pakistani doctor, and then sent him out in the field to give hepatitis B vaccine. His real mission was espionage for the United States, but while gathering biological samples for DNA analysis, his team vaccinated whole neighborhoods without government permission.

Pakistan's polio vaccination campaign was already encountering obstacles, particularly in the Northwest 'tribal regions' of the country. Local leaders there viewed with suspicion vaccinators who came in from outside. Did they have motives other than protecting the region's 300000 children from polio?

More than a year later, in July 20II, The Guardian uncovered the CIA's role ${ }^{2}$ in the sham vaccination activity. Many Pakistanis were angry. This January (2012), the US Defense Secretary confirmed the CIA's use of a vaccination program for espionage. And when the Pakistani doctor was sentenced to jail, anger at the US ruse resurfaced. Aid groups in the United States and abroad have protested to the head of the CIA, decrying the misuse of immunization programs. ${ }^{3}$ And among public health colleagues, Paul Offit (an American pediatrician specializing in infectious diseases who co-invented a rotavirus vaccine credited with saving hundreds of lives every day) was eloquent, but lonely: 'To take children who are in need of vaccines to prevent some disease that would otherwise kill them and use that as a front for something else is unconscionable. The end doesn't always justify the means'. ${ }^{4}$ 
A debate continues about how much damage will ultimately result from the ill-conceived use of vaccinators by the CIA. Pakistan's leading vaccine expert, Zulfiqar Bhutta, has tried to remain optimistic about polio elimination in Pakistan. And the World Health Organization, whose polio campaign in Nigeria encountered many years of opposition from religious fundamentalists, remains uncertain about just how long the setback in Pakistan will last and whether it will spread to other countries.

It is difficult to predict the damage. If the CIA subterfuge does no more than stall polio vaccination in Pakistan, there may be as many as 300 preventable cases each year. The health damage could be much worse if distrust spreads to other vaccines and diseases beyond polio and to other countries - and slows vaccination.

I am troubled by the apparent silence of the US public health officials. On the Web I can find no mention of any comment from the US Public Health Service or even from non-governmental public health groups. Why the silence?

I can think of three possible explanations:

I. The CIA did not consult or even alert the Public Health Service in advance. A possible explanation, but the CIA could not have been unaware that $\mathrm{CDC}, \mathrm{NIH}$, and the FDA all have been engaged in efforts to improve vaccines and vaccination around the world. The Agency for International Development, too, supports vaccination.

2. The Public Health Service was consulted by the CIA. It was informed and had a chance to weigh-in before the CIA used the sham vaccination program to cover espionage. Health officials advised against it because of the obvious damage it could cause to vaccination programs and to the health of children. But perhaps, in the end, they were overruled or ignored - and sworn to secrecy, and the ruse went forward.

3. Or US health officials simply supported the CIA's egregious plan or raised no objection from the start.

Whichever explanation is correct, none justifies the subsequent silence, once the press disclosed the CIA's incredible misjudgment. And none is good for the reputation or credibility of public health in the US government. 
The public health community must not let this awful, and now public, decision pass without being sure that the lessons have been learned and similar errors will never happen again. The intelligence community must consider the health effects of its operations, and if unsure, consult the public health community. The public health community needs to break its silence and never again be silent on matters of public health.

Looking for guidance, I wrote to an old friend from my days working for the Congress. His response was quick. 'We agree about the stupidity of what happened in Pakistan. Avoiding another similar incident is imperative. However, we seem to be experts at repeating our mistakes'. As surely the first step is to speak out, we run this short editorial.

\section{References and Notes}

I. McNeil Jr, D.G. (2OI2) CIA vaccine ruse may have harmed the war on polio. New York Times, 9 July 20I2, http://www.nytimes.com/20I2/07/Io/health/cia-vaccine-ruse-in-pakistan-mayhave-harmed-polio-fight.html?_r=I \& pagewanted=all, accessed 9 August 20 I 2.

2. Shah, S. (20II) CIA organized fake vaccination drive to get Osama bin Laden's family DNA. The Guardian, I I July 20 I I, http://www.guardian.co.uk/world/20 I I/jul/I I/cia-fake-vaccinationsosama-bin-ladens-dna, accessed 9 August 20 I 2.

3. InterAction's letter to CIA director David Petraeus was accessed on 9 August 20 I 2 at http:// www.interaction.org/document/interaction-letter-cia.

4. Laser. (20II) CIA used fake vaccination campaign to seek Osama bin Laden. Allvoices .com, I 5 July, http://www.allvoices.com/contributed-news/9689646-cia-used-fake-vaccinationcampaign-to-seek-osama-bin-laden, accessed I I August 20 I 2.

Anthony Robbins

Co-Editor 